\title{
PERSONAL HYGIENE AND REPRODUCTIVE HEALTH KNOWLEDGE AMONG ADOLESCENTS AT KAMPUNG BELAJAR, SURABAYA
}

\author{
Nuranisah Djunaedi ${ }^{1}$, Yuly Sulistyorini ${ }^{2}$ \\ ${ }^{1.2}$ Faculty of Public Health, Universitas Airlangga, 60115 Surabaya, East Java, Indonesia \\ Corresponding Author: Nuranisah Djunaedi \\ Email: nuranisah.djunaedi-2017@fkm.unair.ac.id
}

\begin{abstract}
Health knowledge is fundamental for everyone, including children. This knowledge provides understanding for children in preparation for entering puberty. However, health education which discusses personal hygiene, anemia, puberty, and healthy relationships, as well as reproductive health is still very limited in formal schools. Because of these limitations, children need to get informal education. One of the ways this is done is through health education activities at Kampung Belajar. The research objective was to analyze health knowledge on personal hygiene, anemia, puberty, healthy relationships, and reproductive health taught through health education at Kampung Belajar in Jambangan, Surabaya. This study used secondary data sources obtained from the teaching team at the learning village. The data obtained were the result of evaluating learning activities related to health knowledge. The research subjects were 22 students from grade 1 to 7 . The results of this study were 0.031 with $p$ $<0.05$. It can be concluded that there was a difference in health knowledge, which included personal hygiene, anemia, puberty, healthy relationships, and reproductive health in the study group after receiving health education provided by the teaching team at Kampung Belajar.
\end{abstract}

Keywords: knowledge, personal hygiene, reproductive health

\section{ABSTRAK}

Pengetahuan kesehatan merupakan hal fundamental diketahui oleh setiap orang termasuk anak-anak. Adanya pengetahuan ini memberikan persiapan bagi anak sebagai dalam memasuki masa pubertas. Akan tetapi, pendidikan kesehatan yang membahas mengenai personal hygiene, anemia, pubertas, dan pergaulan sehat, serta kesehatan reproduksi (kespro) masih sangat terbatas diajarkan di sekolah formal. Akibat keterbatasan tersebut, anak perlu mendapatkan pendidikan informal salah satunya melalui kegiatan pendidikan kesehatan di Kampung Belajar. Penelitian ini menganalisa pengetahuan kesehatan meliputi pengetahuan personal hygiene, anemia, pubertas, dan pergaulan sehat, serta kesehatan reproduksi diajarkan melalui pendidikan kesehatan di Kampung Belajar RT 05 RW III Kelurahan Jambangan, Kota Surabaya. Penelitian menggunakan data sekunder yang diperoleh dari tim pengajar di Kampung Belajar. Data yang diperoleh merupakan hasil evaluasi kegiatan pembelajaran terkait pengetahuan kesehatan. Subjek penelitian berjumlah 22 orang dari siswa kelas 1 SD hingga kelas 7 SMP. Hasil penelitian ini adalah 0,031 pada p<0.05, sehingga dapat disimpulkan ada perbedaan pengetahuan kesehatan yang mencakup pengetahuan personal hygiene, anemia, pubertas dan pergaulan sehat, serta kesehatan reproduksi pada anak-anak kelompok belajar sesudah mendapatkan pendidikan kesehatan yang diberikan oleh tim pengajar di Kampung Belajar.

Kata kunci: pengetahuan, personal hygiene, kesehatan reproduksi

Received: September 12, 2020

Accepted: March 11, 2021

\section{INTRODUCTION}

Health knowledge is basic understanding that is important for children and adolescents. The provision of appropriate and correct health knowledge information can be a provision for children when they enter their teenage years. Basic health education on topics such as personal hygiene, anemia, puberty, and reproductive health can be given to children. However, some of the information, such as puberty, anemia, and reproductive health issues today, tends to focus on teenagers. Ideally, the family environment should be the first source of health information for children and adolescents. However, not all parents can be open with their children in discussing reproductive health (Nurbaya, Jafar, and Asrina, 2019).

A study found that there was still a lack of knowledge among young women about 
puberty in as many as 25 respondents $(61 \%)$. This is because the sources of information obtained were still lacking. As a result, 25 respondents $(61 \%)$ showed an attitude of being indifferent to their physical changes during puberty (Panjaitan, Angelia, and Apriani, 2018). Knowledge of puberty is crucial because the development of puberty in each child or adolescence is different. Children must understand puberty before entering puberty when they are in elementary school. Puberty should be included in the comprehensive sex education provided by the family. However, there is no guarantee that children will get this information from their families (Rašková and Stolinská, 2018).

Research by Zakiyah, Prabandari, and Triratnawati (2016) explained that there are several views of parents on early sexuality education in children, including things that are inappropriate to talk about. This could be because parents view teaching sexuality education as the same as teaching sexual relations to children, and children's comprehension is still considered low for processing this kind of information. Beyond parents' perceptions, other factors hinder conveying sexuality education information to children. This can include parents' ignorance of explaining to children, thinking that children are not ready to discuss these topics, and feeling uncomfortable discussing with their children. Most parents also do not provide information because they judge that sex education is automatically known by their children (Maryuni and Anggraeni, 2017). Due to this condition, the understanding of children and even teenagers regarding health is still minimal. The lack of health education can trigger unwanted things such as sexual harassment, early marriage, pregnancy outside of marriage, abortion, and sexually transmitted infections. It was even found that children received sexual violence treatment that resulted in psychological trauma such as depression, phobias (fear of something), nightmares, suspicion, and suicidal thoughts (Ningsih and Hennyati, 2018).

Information related to reproductive health is summarized in several subjects at school. Materials related to personal hygiene, anemia, reproductive health, puberty at the elementary school level are still only partially understood by the elementary school (SD) and junior high school (SMP) students. Sexuality or reproductive health education materials in a subject are not specifically formed, but are integrated in certain chapters in physical education, science, social sciences, and religion lessons (Utomo et al., 2011). In addition to being integrated with certain subject chapters, there are schools health clinic (UKS) activities where they provide health education such as how to maintain personal hygiene, proper and correct brushing techniques, wound treatment, nail hygiene care, and sex education with the aim of improving the health status of participants or students as early as possible (Efendi and Makhfudli, 2009). Health education at school still does not fully complete the understanding of health information, including reproductive health through UKS. There are still many students who consider UKS as a place for sick people to be given treatment, and only a few understand it as a place to consult or obtain reproductive health information. As a result, students never ask about reproductive health information (Budiono and Sulistyowati, 2013).

One way to increase the knowledge of children or adolescents is through health education, especially about personal hygiene and reproductive health through study groups with the community. Health education is a process of change where impetus begins with self-awareness in individuals and groups or in society to improve health status. The scope of health education is targeted at individuals, groups, and communities through theoretical and practical education (Sari, 2013). It is very important to provide education and to get insight into the children of the study group through health education.

\section{METHODS}

This study used secondary data obtained from the teaching team in the learning village. The data were the result of an evaluation of learning in 2019 where health education activities were carried out by the teaching team at the learning village. Data processing was then carried out with permission from the teaching team. The results of data processing were used as evaluation for teachers in implementing the delivery of material with methods that are easy to understand, not boring, and unique. Secondary data were obtained in the form of 
information on knowledge of the learning group from health education activities by the teaching team. Based on the information from the teacher, teaching was done using the lecture method and the distribution of leaflets according to the themes discussed. The frequency of discussion of the material was only given once at a time with a delivery time of around 30 minutes. Based on data from the teaching team at Kampung Belajar, the population involved were members of study groups at Kampung Belajar in Jambangan, Surabaya. The activities carried out by the teaching team involved all study group children in the Kampung Belajar who were interested in participating in learning activities. The sample size was 22 respondents consisting of school-age children from grade 1 to 7 .

The research variable was health knowledge, which consisted of four categories. The data obtained contained 20 health knowledge questions which were divided into four categories: knowledge of personal hygiene, anemia, puberty and relationships, and reproductive health. The personal hygiene questionnaire consisted of questions about washing hands to keep them clean, ear hygiene, reproductive organ hygiene, nail hygiene, and how to clean genital organs. The anemia knowledge questionnaire contained questions about the definition of anemia, foods that contain iron, how to prevent anemia, and foods that contain good absorption of iron. The puberty questionnaire consisted of questions about the definition of puberty, proper handling of puberty, adolescent curiosity, examples of healthy relationships, how to establish healthy relationships, responses to acts of violence or harassment, and actions to have healthy relationships. The reproductive health questionnaire included questions about the definition of wet dreams, the definition of menstruation, maintaining cleanliness during menstruation, and safe use of sanitary napkins. All knowledge questions were theoretical, and there were no practical measurements related to health behavior. The data were then processed by a statistical test analysis.

The value of each respondent was determined in three levels of knowledge, namely good (14-20), sufficient (7-13), and less (0-6). A score of 1 was given if the answer was correct and a score of 0 was given for wrong answers. Data analysis was done using statistical tests with computer aids. A paired T-Test was used because the distribution of the resulting data was normal and in order to find differences between the variables studied.

\section{RESULTS}

\section{Characteristics of Respondents}

The characteristics of the respondents were seen based on the grouping of gender and class. The grouping was obtained as follows:

Table 1. Distribution of Respondent's Class Level and Gender

\begin{tabular}{rlll}
\hline Class & \multicolumn{2}{c}{ Gender $(\%)$} & Amount \\
\cline { 2 - 3 } Level & \multicolumn{1}{c}{ Man } & \multicolumn{1}{c}{ Woman } & \multicolumn{1}{c}{$(\%)$} \\
\hline Grade 1 & $1(4.55)$ & 0 & $1(4.55)$ \\
Grade 2 & $1(4.55)$ & $1(4.55)$ & $2(9.09)$ \\
Grade 3 & $2(9.09)$ & 0 & $2(9.09)$ \\
Grade 4 & $1(4.55)$ & $4(18.18)$ & $5(22.73)$ \\
Grade 5 & $3(13,62)$ & $4(18.18)$ & $7(31.81)$ \\
Grade 6 & $2(9.09)$ & $2(9.09)$ & $4(18.18)$ \\
Grade 7 & $1(4.55)$ & 0 & $1(4.55)$ \\
\hline Total & $11(50)$ & $11(50)$ & $22(100)$ \\
\hline Source: & Secondary & Data of the & Learning \\
Village, 2019 & &
\end{tabular}

Table 1 shows the number of respondents who took part in health education learning, with an equal number of male and female respondents consisting of 11 respondents of each gender (50\%). Based on the class, the respondents were dominated by 5 th-grade elementary school children with as many as seven respondents $(31.8 \%)$.

Table 2 cumulatively shows that the percentage of personal hygiene knowledge in respondents increased after being given reproductive health education. A significant increase in knowledge was found in the indicators of maintaining the cleanliness of the reproductive organs, with an increase from 10 respondents $(45.45 \%)$ to 16 respondents $(72.73 \%)$. Besides, correct answers related to how to clean the reproductive organs also increased from 4 respondents (18.18\%) to 10 respondents $(45.45 \%)$. 
Health Knowledge Based On Pre-Test and Post-Test of Each Category

Table 2. Personal Hygiene Knowledge

\begin{tabular}{lcc}
\hline \multirow{2}{*}{ Variables } & \multicolumn{2}{c}{ Number of Respondents (\%) } \\
\cline { 2 - 3 } How to Wash Hands & Post-test \\
\hline Right & $19(86.36)$ & $20(90.91)$ \\
Wrong & $3(13.64)$ & $2(9.09)$ \\
Frequency & \multicolumn{3}{c}{22} \\
\hline Ear Hygiene & \multicolumn{3}{c}{$22(100)$} \\
\hline Right & $21(95.45)$ \\
Wrong & $1(4.55)$ \\
Frequency & \multicolumn{3}{c}{22} \\
\hline Reproductive Organ Hygiene \\
\hline Right & $10(45.45)$ & $16(72.73)$ \\
Wrong & $12(54.55)$ & $6(27.27)$ \\
Frequency & \multicolumn{3}{c}{22} \\
\hline Nail Hygiene & \multicolumn{3}{c}{$19(86.36)$} \\
\hline Right & $17(77.27)$ \\
Wrong & $5(22.73)$ & $3(13.64)$ \\
Frequency & \multicolumn{3}{c}{22} \\
\hline How to Clean the Reproductive Organs \\
\hline Right & $4(18.18)$ & $10(45.45)$ \\
Wrong & $18(81.82)$ & $12(54.55)$ \\
Frequency & \multicolumn{3}{c}{22} \\
\hline$\sum$ Right & 64.54 \\
\hline$\sum$ Wrong & 35.44 \\
\hline Source Second & 20.91 \\
\hline
\end{tabular}

Source: Secondary Data of the Learning Village, 2019

In general, there was an increase in respondents' knowledge about anemia after receiving information about health in the learning village from $44.31 \%$ to $50.01 \%$. Indicators increased were knowledge of the definition of anemia, foods that contain iron, and how to prevent anemia. On the indicator of knowledge about iron absorption, before respondents received information on health education and personal hygiene as many as 7 respondents $(31.83 \%)$ were able to answer correctly, and this number then decreased to 3 respondents $(13.64 \%)$. The highest increase in respondents' knowledge occurred in knowledge about how to prevent anemia from $36.36 \%$ to $63.64 \%$ after receiving education about reproductive health and personal hygiene.
Table 3. Anemia Knowledge

\begin{tabular}{|c|c|c|}
\hline \multirow[t]{2}{*}{ Variables } & \multicolumn{2}{|c|}{$\begin{array}{c}\text { Number of Respondents } \\
(\%)\end{array}$} \\
\hline & Pre-test & Post-test \\
\hline \multicolumn{3}{|c|}{ Definition of Anemia } \\
\hline Right & $18(81.82)$ & $20(90.91)$ \\
\hline Wrong & $4(18.18)$ & $2(9.09)$ \\
\hline Frequency & \multicolumn{2}{|c|}{22} \\
\hline \multicolumn{3}{|l|}{ Iron Food } \\
\hline Right & $6(27.27)$ & $7(31.82)$ \\
\hline Wrong & $16(72.73)$ & $15(68.18)$ \\
\hline Frequency & \multicolumn{2}{|c|}{22} \\
\hline \multicolumn{3}{|c|}{ Anemia Prevention } \\
\hline Right & $8(36.36)$ & $14(63.64)$ \\
\hline Wrong & $14(63.64)$ & $8(36.36)$ \\
\hline Frequency & \multicolumn{2}{|c|}{22} \\
\hline \multicolumn{3}{|c|}{ Iron Absorption } \\
\hline Right & $7(31.82)$ & $3(13.64)$ \\
\hline Wrong & $15(68.18)$ & $19(86.36)$ \\
\hline Frequency & \multicolumn{2}{|c|}{22} \\
\hline$\sum$ Right & 44.31 & 50.01 \\
\hline$\sum$ Wrong & 55.69 & 49.99 \\
\hline $\begin{array}{l}\text { ource: } \mathrm{Se} \\
\text { Village, } 201\end{array}$ & y Data & he Learn \\
\hline
\end{tabular}

Respondents' knowledge about puberty and healthy relationships increased after attending health and personal hygiene education, from $57.14 \%$ of respondents who answered correctly before getting the information to $70.78 \%$ afterward. From the seven indicators on the variable knowledge of puberty and healthy relationships, only two indicators saw an increase, namely knowledge questions about appropriate handling of puberty and adolescent curiosity. Increased knowledge of adolescent curiosity was higher than knowledge about handling puberty. Meanwhile, the indicators of knowledge about the definition of puberty, examples of healthy relationships, and healthy relationships decreased. Among the three indicators, knowledge on how to have healthy relationships experienced the most decline. Meanwhile, there was no change in adolescent knowledge about violence prevention and healthy social activities. The percentages on both indicators were constant, both before and after the 
intervention in the form of health education about personal hygiene and reproductive health (Table 5).

Table 4. Knowledge of Puberty and Healthy Association

\begin{tabular}{llr}
\hline \multirow{2}{*}{ Variables } & \multicolumn{2}{c}{$\begin{array}{c}\text { Number of Respondents } \\
(\%)\end{array}$} \\
\cline { 2 - 3 } & Pre-test & Post-test \\
\hline Definition of Puberty & $12(54.55)$ \\
\hline Right & $14(63.64)$ & $10(45.45)$ \\
Wrong & $8(36.36)$ & \\
Frequency & 22 \\
\hline Handling Puberty & $12(54.55)$ \\
Right & $9(40.91)$ & $10(45.45)$ \\
Wrong & $13(59.09)$ & \\
Frequency & \multicolumn{2}{c}{22} \\
\hline
\end{tabular}

\begin{tabular}{|c|c|c|}
\hline \multicolumn{3}{|c|}{ Teenage Curiosity } \\
\hline Right & $14(63.64)$ & $18(81.82)$ \\
\hline Wrong & $8(36.36)$ & $4(18.18)$ \\
\hline Frequency & \multicolumn{2}{|c|}{22} \\
\hline
\end{tabular}

Examples of Healthy Association

\begin{tabular}{lcc}
\hline Right & $20(90.91)$ & $19(86.36)$ \\
Wrong & $2(9.09)$ & $3(13.64)$ \\
Frequency & \multicolumn{2}{c}{22} \\
\hline How to Have Healthy Relationships \\
\hline Right & $17(77.27)$ & $14(63.64)$ \\
Wrong & $5(22.73)$ & $8(36.36)$ \\
Frequency & \multicolumn{2}{c}{22} \\
\hline
\end{tabular}

Violence Prevention Measures

\begin{tabular}{lcl}
\hline Right & $20(90.91)$ & $20(90.91)$ \\
Wrong & $2(9.09)$ & $2(9.09)$ \\
Frequency & \multicolumn{2}{c}{22} \\
\hline Healthy Association Action \\
\hline Right & $14(63.64)$ & $14(63.64)$ \\
Wrong & $8(36.36)$ & $8(36.36)$ \\
Frequency & \multicolumn{2}{c}{22} \\
\hline L Right & 57.14 & 70.78 \\
\hline L Wrong & 42.86 & 29.22 \\
\hline
\end{tabular}

Source: Secondary Data of the Learning Village, 2019

Table 5 shows an increase in respondents' knowledge about reproductive health by $5.56 \%$ after receiving information and education from the learning village. Of the four indicators related to reproductive health knowledge, respondents who answered correctly on the variable definition of wet dreams and menstruation experienced an increase after being given health education materials. Knowledge about the definition of wet dreams increased higher than the knowledge about the definition of menstruation (increased by 27.27\%). Meanwhile, two other indicators, namely knowledge about hygiene during menstruation and safe sanitary napkins, actually decreased.

Table 5. Reproductive Health Knowledge

\begin{tabular}{|c|c|c|}
\hline \multirow{2}{*}{ Variables } & \multicolumn{2}{|c|}{$\begin{array}{c}\text { Number of Respondents } \\
(\%)\end{array}$} \\
\hline & Pre-test & Post-test \\
\hline \multicolumn{3}{|c|}{ Definition of Wet Dream } \\
\hline Right & $7(31.82)$ & $13(59.09)$ \\
\hline Wrong & $15(68.18)$ & $9(40.91)$ \\
\hline Frequency & \multicolumn{2}{|c|}{22} \\
\hline \multicolumn{3}{|c|}{ Definition of Menstruation } \\
\hline Right & $9(40.91)$ & $10(45.45)$ \\
\hline Wrong & $13(59.09)$ & $12(54.55)$ \\
\hline Frequency & \multicolumn{2}{|c|}{22} \\
\hline \multicolumn{3}{|c|}{ Hygiene During Menstruation } \\
\hline Right & $10(45.45)$ & $9(40.91)$ \\
\hline Wrong & $12(54.55)$ & $13(59.09)$ \\
\hline Frequency & \multicolumn{2}{|c|}{22} \\
\hline \multicolumn{3}{|c|}{ Safe Sanitary } \\
\hline Right & $21(95.45)$ & $20(90.41)$ \\
\hline Wrong & $1(4.55)$ & $2(9.09)$ \\
\hline Frequency & \multicolumn{2}{|c|}{22} \\
\hline$\sum$ Right & 53.40 & 58,96 \\
\hline$\sum$ Wrong & 46.59 & 40.91 \\
\hline
\end{tabular}

Source: Secondary Data of the Learning Village, 2019

\section{Respondents' Health Knowledge}

Based on Table 6, respondents who hade good knowledge of health increased their scores from $27.3 \%$ (6 respondents) to $36.4 \%$ (8 respondents). The number of respondents who had sufficient knowledge before being given health education was 16 people $(72.7 \%)$, which decreased to 14 people $(63.6 \%)$ after being given health education which included the four categories of discussion. The details of increasing respondents' health knowledge 
based on the four categories are discussed in more detail in Table 2, Table 3, Table 4, and Table 5 regarding knowledge of reproductive health.

Table 6. Respondents Health Knowledge Results (Pre-Test and Post-Test)

\begin{tabular}{|c|c|c|}
\hline \multirow{2}{*}{$\begin{array}{l}\text { Knowledge } \\
\text { Category } \\
\text { Health }\end{array}$} & \multicolumn{2}{|c|}{$\begin{array}{c}\text { Number of Respondents } \\
(\%)\end{array}$} \\
\hline & Pre-test & Post-test \\
\hline Well & $6(27.3)$ & $8(36.4)$ \\
\hline Enough & $16(72.7)$ & $14(63.6)$ \\
\hline Total & \multicolumn{2}{|c|}{$22(100)$} \\
\hline $\begin{array}{l}\text { Paired } \\
\text { Samples Test }\end{array}$ & \multicolumn{2}{|c|}{ Results } \\
\hline \multirow{4}{*}{$\begin{array}{l}\text { Pre-test and } \\
\text { Post-test }\end{array}$} & $R$ & Sig. \\
\hline & 0.458 & 0.032 \\
\hline & df & Sig. 2-tailed \\
\hline & 21 & 0.031 \\
\hline
\end{tabular}

Source: Secondary Data of the Learning Village, 2019

The results of the statistical test of paired samples correlations showed that there was a significant positive relationship with the value of $r=0.458$ on the pre-test and post-test knowledge measurements, which obtained a pvalue of $(0.032)<(0.05)$. The paired samples test tailed displayed 0.031 at $p<(0.05)$, meaning that there was a difference in knowledge of the respondents after receiving health education in the study group.

\section{DISCUSSION}

The findings of this study indicate that there was a change in respondents' knowledge after being given health education, with an increase in good knowledge from $27.3 \%$ pretest to $36.4 \%$ post-test. Based on the calculation of the paired sample T-test of 0.031 $<(0.05)$, there was a difference in knowledge before and after health education was given. Health education is a voluntary action carried out through education to promote health, prevent disease, disability, and death. It is privately focused on increasing knowledge, attitudes, skills, and health behaviors with various approaches (World Health Organization, 2012). Provision of health information must be accompanied by adults such as parents or teachers because children are very vulnerable to misperceiving information. The conclusion of this study is that health education has an impact on changes in respondents' knowledge, which includes knowledge of personal hygiene variables, anemia, puberty and healthy relationships, and reproductive health.

The level of good personal hygiene knowledge increased from $64.54 \%$ to $79.09 \%$. This is in line with research results by Fatmawati (2018), which showed that the provision of health materials about personal hygiene increased knowledge by $15 \%$, namely from $60 \%$ to $75 \%$ of students. Likewise, Limbong (2018) showed that students experienced an increase in knowledge and changes in attitudes towards personal hygiene from $47.7 \%$ to $52.5 \%$ after receiving health education about personal hygiene. Personal hygiene is a practice carried out to maintain body hygiene which is implemented through bathing, maintaining hair hygiene, washing hands with soap, brushing teeth, cutting nails, and cleaning ears. Personal hygiene practices must be instilled in children from an early age, for example, the habit of washing hands properly to prevent disease transmission, especially infectious diseases (Kericho and Rebecca, 2016).

Knowledge of the anemia variable increased from $44.31 \%$ to $50.01 \%$ after being given an education. However, there was a topic where knowledge did not increase after being given health education, namely iron absorption. The results of the pre-test showed that only seven respondents $(31.82 \%)$ were able to answer correctly, and after being given health education it dropped to three respondents $(13.64 \%)$. This result is in line with the findings in a study by Sulistyowati, Rahfiludin, and Kartini (2019) where the understanding of vegetables with iron deficiency $83.3 \%$ (30 respondents) decreased to $80.6 \%$ (29 respondents). An increase in knowledge did not occur because respondents did not understand the points of the material on iron absorption regarding the iron content in vegetables and iron in animal products, namely meat. On the other hand, limited time, and time distribution for conveying more about foods that contain iron were the reasons why indicators of understanding iron absorption was not achieved. In addition, it could be because the method used, namely lectures, caused the 
children and adolescents to become bored with paying attention to the material. As a result, this may have reduced their focus on understanding the information explained.

A study was done by Suci and Purwidiani (2020) on applying interesting methods in delivering material about anemia with pop-up book media. This method affected learning outcomes, with the post-test percentage of students being $8.75 \%$ from the initial value of $5.656 \%$. The use of pop-up book media had a positive reaction on students' interest in learning, resulting in the learning outcomes being categorized as very good. Teachers are advised to try unique learning strategies by explaining the material with the help of visual media, for example, with a pop-up book about nutritious food and anemia.

Variable knowledge of puberty and relationships increased from $57.14 \%$ to $70.78 \%$. In line with research results from Husain and Sabur (2020) regarding puberty, 13 respondents $(28.89 \%)$ had good knowledge before being given puberty material, and attitude with good category as much as 1 respondent $(2.22 \%)$. After being given puberty education, the knowledge of respondents increased by 45 people (100\%) and attitude by 43 people $(95.56 \%)$. However, from this research, there were indicators of declining knowledge of respondents who found it quite difficult to understand. This included the definition of puberty, examples of healthy relationships, and healthy ways of socializing such as being good at choosing friends. The results of the pre-test dropped from $77.27 \%$ (17 respondents) to $63.64 \%$ (14 respondents) posttest. Post-test results decreased because respondents were still confused about puberty and healthy relationships. The discussion of the topic used the same method as other topics, namely lectures. This method is considered not appropriate in changing the views of children and adolescents because there is no reciprocal process during the material and lectures are usually given in schools, making respondents less enthusiastic. However, unique methods such as brainstorming with colored paper media increase the enthusiasm of children and adolescents in participating in activities and expressing their opinions (Astri, Winarni, and Dharmawan, 2016). Because of this, regarding the material on puberty and healthy relationships, it is recommended to implement several improvised methods such as lectures and brainstorming methods. The lecture method could cause some children to be embarrassed in expressing their opinions. Both methods may be applied to allow teachers and children to go back and forth verbally and nonverbally, namely through writing, as well as help teachers find out the extent of individual capture through the answers they write on the paper provided.

Making friends or socializing is important in childhood and adolescence. Friends can influence the motivation and attitudes of adolescents in supporting certain behaviors, such as risky behavior. This condition is related to social learning, where students learn specific behaviors through observation and imitating their peers. Peers have a dominant influence on adolescent selfconcept. Adolescent self-concept is related to knowledge about oneself obtained through social relations in the community. It affects individuals in receiving information and taking action. In addition to having a positive impact, peer groups become dangerous if they tend to be closed, for example, if members cannot quit/leave the group (Saraswatia, Zulpahiyana, and Arifah, 2015). As a result, children and adolescents need to know information about puberty and healthy relationships.

Reproductive health information needs to be provided from an early age, because with education, children and adolescents learn the dangers that arise from risky behavior, how to take care of themselves, and how to grow into children with responsible attitudes towards maintaining reproductive health (Panjaitan, Djuanda and Hanifah, 2015). The level of knowledge of respondents on reproductive health variables increased from $53.90 \%$ to $58.96 \%$. This is similar to research by Nugraheni et al. (2018), who found changes in the level of knowledge in 70 elementary school students regarding reproductive health. Before being given reproductive health education as many as 10 respondents (14.3\%) were able to answer correctly. After being given reproductive health education, this number increased to $72.9 \%$ (51 respondents) who were able to answer correctly. However, there were indicators of questions that have not increased respondents' knowledge, namely maintaining cleanliness during menstruation and safe use of sanitary napkins. This could have been influenced by the delivery method 
which has less effect on the respondents' knowledge. Materials on reproductive health were delivered through lectures and distributing leaflets related to the material presented.

To increase knowledge, media leaflets must be read repeatedly. However, this method is less effective during the process of delivering material at the same time as a lecture. More interesting methods of educating could be done through group discussions with the help of flipcharts. Through group discussions, new ideas for teenagers can be explored more deeply. The effectiveness of this method was proven by Bahri (2018), who found that the knowledge of elementary school students about menstrual hygiene in the intervention group, namely group discussion, increased more post-test than the group that was only given leaflets. This explains the material that is quite difficult, such as hygiene during menstruation and sanitary napkins, should not only be taught through leaflets, but should be supported by group discussions with the help of flipcharts to allow respondents to think of new ideas and convey their own ideas. On the other hand, providing interactive books about menstruation that are more visualized and colorful is very important to increase knowledge, especially for girls. The existence of interactive books makes it easier for students to remember the material and understand it. For example, the design of the Menstrupedia book by Malinda, Damajanti, and Muljosumarto (2017) may give positive reactions and curiosity for children because the visualization of funny and bright books makes it easier for children to understand the contents of the material such as the subject of menstruation and its cycle, changes in the body before menstruation, tips for dealing with physical changes when dealing with menstruation, sanitary napkins, as well as appeals to maintain body hygiene during menstruation.

\section{CONCLUSIONS AND SUGGESTIONS}

\section{Conclusion}

The findings of this study describe that differences in knowledge were found in respondents after being given education through health education. Before respondents received education from health education, there were 6 respondents $(27.3 \%)$ with good knowledge and 16 respondents $(72.7 \%)$ with sufficient knowledge. After the lessons, there were 8 respondents $(36.4 \%)$ with good knowledge and 14 respondents $(63.6 \%)$ with sufficient knowledge. There were four variables of health knowledge measured in this study, namely knowledge of personal hygiene, anemia, puberty and healthy relationships, and knowledge of reproductive health. The knowledge material that was categorized as adequate with a correct answer range of 7-13 between pre-test and post-test was material on how to clean the reproductive organs, foods containing iron, handling puberty, and the definition of wet dreams.

The results of the statistical test resulted in the $\mathrm{p}$-value of 0.031 , meaning there were differences in the knowledge that included personal hygiene, anemia, puberty, and healthy relationships, as well as reproductive health in respondents after attending health education provided by the teaching team at Kampung Belajar. Moreover, from the various materials presented, five topics were not understood and digested properly by the study group. This can be seen from the decreased knowledge post-test. These discussions were on iron absorption, examples of healthy relationships, healthy social practices, maintaining cleanliness during menstruation, and safe use of sanitary napkins.

\section{Suggestion}

The process of providing a good understanding of health knowledge for children and adolescents requires intensive education or provision of health materials in Kampung Belajar. The more often they are exposed to health information, the more it can increase knowledge and influence the health behavior of children and adolescents. Health education can be developed through a variety of learning methods, for example using audiovisual media, brainstorming methods by writing answers on colored paper, practical methods, utilizing pop-up books, and providing interactive books on health to develop health literacy insights for children and adolescents in study groups. Further, it is recommended that the delivery of each material be carried out in stages with separate themes. For example, the first week could discuss personal hygiene, the second week anemia, the third week puberty and healthy relationships, and the fourth week reproductive 
health. The discussion being carried out in stages helps the teacher observe the development of children's understanding of each material. This also allows teachers to consider the application of unique methods in various discussion sessions.

\section{REFERENCES}

Astri, L.A., Winarni, S. and Dharmawan, Y., 2016. Pengaruh Pemberian Pendidikan Kesehatan Reproduksi terhadap Tingkat Pengetahuan Remaja Awal Sekolah Dasar di Daerah Wisata Bandungan, Kabupaten Semarang Tahun 2016. Jurnal Kesehatan Masyarakat (e-Journal), 4(4), pp.213219.

Bahri, N.A.H., 2018. Pengaruh Penyuluhan Kesehatan Reproduksi dengan Metode Diskusi Kelompok terhadap Pengetahuan dan Sikap Menstrual Hygiene Siswi SD Negeri Wilayah Kecamatan Jabung. Universitas Brawijaya.

Budiono, A.M. and Sulistyowati, M., 2013. Peran UKS (Usaha Kesehatan Sekolah) dalam Penyampaian Informasi Kesehatan Reproduksi Terhadap Siswa SMP Negeri X di Surabaya. Promkes Unair, 1(2), pp.184-191.

Efendi, F. and Makhfudli, 2009. Keperawatan Kesehatan Komunitas Teori dan Praktik dalam Keperawatan. 1st ed. [online] Jakarta: Salemba Medika. Available at: <https://books.google.co.id/>.

Fatmawati, T.Y., 2018. Pengetahuan Tentang Personal Hygiene pada Anak Usia Sekolah di SDN 206 / IV Kota Jambi. Jurnal Akademika Baiturrahim, 7(1), pp.10-16.

Husain, H. and Sabur, F., 2020. Pengaruh Pendidikan Kesehatan Terhadap Peningkatan Pengetahuan dan Sikap Siswi SD Kelas 4 dan 5 Tentang Perubahan Fisik Menjelang Masa Pubertas di SD Inpres Sambung Jawa 3 Makassar. Media Kebidanan, 1(1), pp.9-14.

Kericho, J. and Rebecca, K., 2016. The Implementation of Hygiene Practices in Early Childhood Education Centers in Londiani Sub-County,
Kericho County. International Journal of Education and Development, 4(9), pp.46-52.

Limbong, M., 2018. Pengaruh Pendidikan Kesehatan Tentang Personal Hygiene terhadap Pengetahuan dan Sikap Siswa. Excellent Midwifery Journal, 1(1), pp.39-45.

Malinda, N.T., Damajanti, M.N. and Muljosumarto, C., 2017. Perancangan Buku Interaktif Tentang Menstruasi Pertama Untuk Anak Perempuan Usia 9-12 Tahun. Jurnal DKV Adiwarna, 1(10), pp.1-9.

Maryuni and Anggraeni, L., 2017. Faktor yang Berhubungan dengan Tingkat Pengetahuan Orang Tua Tentang Pendidikan Seks Secara Dini pada Anak Sekolah Dasar (SD). Jurnal Ners dan Kebidanan Indonesia, 4(3), pp.135-140.

Ningsih, E.S.B. and Hennyati, S., 2018. Kekerasan Seksual Pada Anak di Kabupaten Karawang. Jurnal Bidan "Midwife Journal", 4(02), pp.56-65.

Nugraheni, S.A., Wahyuningsih, S.E., Prihatini, I.J. and Sulistyowati, E., 2018. Knowledge and Attitudes About Reproductive Health (Preliminary Study on Elementary School in Brebes District, Central Java, Indonesia). International Journal of Community Medicine and Public Health, 5(4), pp.1298-1303.

Nurbaya, Jafar, N. and Asrina, A., 2019. Gambaran Pengetahuan Tentang Pencegahan Kekerasan Seksual Pada Anak Remaja Awal di SD Islam Terpadu Nurul Fikri Makassar. In: Sinergitas Multidisiplin Ilmu Pengetahuan dan Teknologi. Makassar: Yayasan Pendidikan dan Research Indonesia.pp.65-71.

Panjaitan, A.A., Angelia, S. and Apriani, N., 2018. Respon Remaja Putri dalam Menghadapi Perubahan Fisik Saat Pubertas. Berkala Kesehatan, 4(2), pp.55-60.

Panjaitan, R.L., Djuanda, D. and Hanifah, N., 2015. Persepsi Guru Mengenai Sex Education di Sekolah Dasar Kelas VI. Mimbar Sekolah Dasar, 2(2), pp.224233.

Rašková, M. and Stolinská, D.P., 2018. Knowledge About Puberty Among 
Primary School Children in the Czech Republic. In: D.P. Stolinská, ed. International Conference of Education, Research and Innovation (ICERI) 2018 Proceedings. Seville, Spain: International Conference of Education, Research and Innovation.pp.7790-7796.

Saraswatia, G.K., Zulpahiyana and Arifah,S., 2015. Faktor-Faktor yang Mempengaruhi Konsep Diri Remaja di SMPN 13 Yogyakarta. Jurnal Ners dan Kebidanan Indonesia, 3(1), pp.33-38.

Sari, I.P.T.P., 2013. Pendidikan Kesehatan Sekolah Sebagai Proses Perubahan Perilaku Siswa. Jurnal Pendidikan Jasmani Indonesia, 9(2), pp.141-147.

Suci, N.W. and Purwidiani, N., 2020. Pengembangan Media Pembelajaran Pop Up Book pada Materi Pencegahan Anemia untuk Siswa SD. Jurnal Tata Boga, 9(1), pp.576-583.

Sulistyowati, A.M., Rahfiludin, M.Z. and Kartini, A., 2019. Pengaruh Penyuluhan dan Media Poster Tentang Anemia Terhadap Tingkat Pengetahuan dan Sikap pada Santriwati (Studi di Pondok Pesantren Al-Bisyri Kota Semarang). Jurnal Kesehatan Masyarakat (e-Journal),
7(4), pp.700-707.

Utomo, I.D., McDonald, P., Hull, T., Reimondos, A. and Utomo, A., 2011. Policy Brief No. 3 Hasil Positif Pendidikan Kesehatan Reproduksi, HIV dan AIDS di Sekolah Dasar dan Menengah: Bukti dari Jakarta, Jawa Barat, Nusa Tenggara Barat, dan Sulawesi Selatan. 3. [online] Australian Demographic and Social Research Institute. Available at: <https://kebijakankesehatanindonesia. net/> [Accessed 10 Aug. 2020].

World Health Organization, 2012. Health Education: Theoretical Concepts, Effective Strategies and Core Competencies. [online] Health Promotion Practice, Eastern Mediterranean: World Health Organization. Available at: <https://applications.emro.who.int/>.

Zakiyah, R., Prabandari, Y.S. and Triratnawati, A., 2016. Tabu , Hambatan Budaya Pendidikan Seksualitas Dini Pada Anak di Kota Dumai. BKM Journal of Community Medicine and Public Health, 32(9), pp.323-330. 